INFORMASI: Kajian Ilmu Komunikasi - ISSN (p) o126-0650; ISSN (e) 2502-3837

Vol. 48, No. 1 (2018), pp.125-138. doi: http://dx.doi.org/10.21831/informasi.v48i1.1509o

\title{
KPK: KORBAN BALAS DENDAM POLRI (ANALISA NARATIF MODEL GREIMAS PADA KARAKTER KPK DAN POLRI DI MAJALAH TEMPO)
}

\author{
Anastasia Yuni Widyaningrum \\ Anastasia_widya@ukwms.ac.id \\ Noveina Silviyani Dugis \\ Noveina.dugis@gmail.com \\ Dosen Ilmu Komunikasi Fakultas Ilmu Komunikasi \\ Universitas Katolik Widya Mandala Surabaya
}

\begin{abstract}
The reporting of KPK and Polri in is interesting when viewed as a series of films or fictional stories. This research tries to dissect how the narrative model Algirdas Greimas can be used to read the relation of characters that appear in a story like fiction. Using the main report of three Tempo editions selected among the Nine Tempo editions containing KPK and Polri reporting in 2015. Three of nine editions were selected in the middle as the culmination of the story of the entire series of KPK-Polri reporting stories. Using the actan model of Algirdas Greimas, it was found that the parties involved in the KPK-Polri story consisted of many people who, if assembled in actor model relationships, would find a knot that the conclusion of this study was that the KPK was narrated as a weak party, full of problems, and violate ethics so it must be handled and resolved by the Polri. In these three stories, Polri, represented by Bareskrim, is narrated as an institution that protects and controls the violation of the Law. The KPK is then represented as the wrong party for violating the rules, while the POLRI is the right party because it enforces the rules.
\end{abstract}

\section{Abstrak}

Pemberitaan KPK dan Polri di majalah Tempo menjadi menarik ketika dilihat sebagai sebuah rangkaian kisah film ataupun kisah fiksi. Maka penelitian ini berusaha untuk membedah bagaimana model narasi Algirdas Greimas dapat digunakan untuk membaca relasi karakter yang muncul dalam sebuah pemberitaan layaknya kisah fiksi. Penelitian ini menggunakan laporan utama tiga edisi Tempo yang dipilih diantara Sembilan edisi Tempo yang memuat pemberitaan KPK Polri pada tahun 2015. Tiga dari sembilan edisi, dipilih tiga edisi di bagian tengah sebagai puncak kisah dari seluruh rangkaian kisah pemberitaan KPK-Polri. Menggunakan model actan dari Algirdas Greimas, didapatkan data bahwa pihak yang terlibat dalam kisah KPK-Polri terdiri dari banyak orang yang saling berelasi. Kesimpulan dari penelitian ini, KPK dinarasikan sebagai pihak lemah, penuh dengan masalah, dan melanggar etika dan hokum sehingga harus ditangani 
dan diselesaikan oleh Bareskrim Polri. Dalam ketiga kisah ini, POLRI yang diwakili Bareskrim dinarasikan sebagai lembaga yang mengayomi dan melakukan penertiban terhadap pelanggaran Undang-Undang. KPK kemudian direpresentasikan sebagai pihak yang salah karena melanggar aturan, sedangkan POLRI adalah pihak yang benar karena menegakkan aturan.

Keywords: KPK, Polri, Narrative, Actan Model, Algirdas Greimas.

\section{PENDAHULUAN}

Perseteruan KPK-POLRI 2015 menarik sekal seperti kisah laga dalam film. Analisis difokuskan pada tiga laporan utama Tempo Februari 2015. Kisah perseteruan KPKPOLRI dinarasikan bertepatan momen penangkapan Bambang Widjojanto23Januari 2015. Bambang Widjojanto (Wakil Ketua KPK). Bambang sebagai repesentasi KPK menjadikan kapasitas dan kredibilitasnya dipertanyakan.

Untuk membedah kasus KPK-POLRI jilid 2, menggunakan tiga edisi terbitan Tempo yaitu: Edisi 2-8 Februari 2015 "PeluruPeluru Pembunuh Cicak", Edisi 9-15 Februari 2015 "Dalam Bidikan Koalisi Besar." Edisi 16-22 Februari 2015 "Malam di Restoran Cepat Saji." Media massa tidak lepas dari konstruksi realitas dari pekerja media. Tugas redaksional media massa yang terdiri dari wartawan, editor, redaktur, redaktur pelaksana, dan pemimpin redaksi adalah menceritakan kembali peristiwa-peristiwa tersebut. Isi media merupakan realitas yang telah dikonstuksikan (construct reality) oleh pekerja media. (Birowo-editor, 2004:168).

Penelitian ini menggunakan analisa Narrative dengan model Actan oleh Algirdas Greimas. Dalam catatan Elliot (2005) berdasarkan kajian Chatman (1978) Leitch, 1986; Martin, 1986, mengatakan bahwa definisi yang paling sederhana dari narrative (selanjutnya dalam penelitian ini disebut sebagai narasi/ analisis naratif) adalah berawal dari puisi Aristoteles yang ceritanya terdiri dari awal, tengah dan akhir. Munculnya berbagai tokoh dan karakter dalam laporan investigasi Tempo membuat kisah rumit dalam cerita versi Tempo ini kian menarik. Dalam kajian media massa, laporan investigasi merupakan karya jurnalistik yang terbilang rumit dan penuh tantangan untuk dilakukan karena menuntut integritas diri dan kemampuan handal dari sang wartawan. Selain itu, karya investigasi juga sering dikaitkan dengan persoalan fakta dan kebenaran serta unsur obyektivitas beritanya. Terlepas dari semuanya itu, sebagai majalah berita, Tempo telah mendedikasikan dirinya sebagai karya jurnalistik yang 'enak dibaca dan perlu' sebagai ciri khas dari karya investigasi dengan gaya bertutur sastrawi. Hal ini senada dengan yang disampaikan oleh Bill Kovach \& Tom Rosenstiel dalam Harsono (2010: 26) yang menyatakan salah satu fungsi dari jurnalistik adalah sebagai pemantau kekuasaan dan penyambung aspirasi yang tertindas, dengan cara melakukan laporan investigasi. Laporan investigasi merupakan jenis reportase dimana si wartawan berhasil menunjukkan siapa yang salah, yang melakukan pelanggaran hukum, yang seharusnya jadi terdakwa, dalam suatu kejahatan publik yang sebelumnya dirahasiakan. Lebih lanjut, Mencher (dalam Santana, 2009:145) juga menjelaskan sumber pemberitaan pers terbagi menjadi dua, pertama, sumber yang bersifat fisik (physical sources), seperti rekaman, dokumen, kertas kerja, kliping dan koran. Kedua, sumber yang bersifat human (human sources), seperti otoritas dan orang-orang yang terlibat dengan sebuah kejadian. Maka itulah, dalam mempergunakan sumber informasi yang bersifat human, para wartawan mesti mendapatkanorangyang memiliki kualifikasi untuk berbicara - memiliki otoritas terhadap subjek permasalahan, seorang saksi mata, para petugas yang terkait dan partisipan yang berhubungan erat dengan topik yang tengah diteliti. 
Peneliti membedah teks laporan utama Tempo dengan berfokus pada karakter yang tidak hanya melihat pada satu karakter, namun yang terpenting adalah bagaimana relasi yang terjalin antar karakter tersebut. Eriyanto (2013: hal. 99) menjelaskan karakter dalam sebuah narasi tidak mucul secara tunggal, namun kehadirannya selalu bersama dengan karakter lain dalam sebuah relasi. Relasi karakter tersebut menjelaskan model aktan yang bekerja melalui relasi dari masing-masing karakter.

Penyajian analisis masing-masing artikel pada bahasan mengenai KPK: Korban Balas Dendam POLRI ini dibagi dalam beberapa babak (sequence), layaknya sebuah film. Dimana masing-masing sequence tersebut dianalisis karakter-nya dengan model Greimas yang menggunakan tiga langkah, yaitu: (1) Profil dari karakter yang terlibat; (2) Pemetaan relasi antar karakter dengan model Aktan; (3) Analisis relasi karakter dalam narasi. Ketiga tahapan analisis dan pembahasan tersebut dilakukan secara menyeluruh oleh peneliti untuk menjaga alur pembahasan dalam subbab ini.

\section{METODE}

Dalam analisis narasi, salah satu unsur yang penting unyuk melihat bagaimana struktur narasi dikisahkan kembali adalah dengan memperhatikan bagaimana karakter dalam kisah tersebut ditampilkan. Selain struktur narasi, unsur karakter menjadi kunci dalam menganalisis sebuah narasi. Dalam Eriyanto (2013: 95) dijelaskan bahwa terdapat dua tokoh yang menawarkan cara menganalisis karakter dalam narasi, yaitu Vladimir Propp dan Algirdas Greimas. Propp membagi fungsi karakter menjadi 31 dan membagi karakter menjadi tujuh, dimana masing-masing karakter memiliki fungsi yang berbeda dan merupakan turunan dari 31 fungsi yang disebutkan oleh Propp. Sedangkan Greimas karakter dalam narasi bisa dilihat dengan cara yang lebih sederhana yakni dengan memfokuskan pada relasi antar karakter.

Dalam penelitian ini model analisis karakter yang digunakan adalah model Greimas yang menekankan bukan hanya posisi karakter saja melainkan juga relasi dari masing-masing karakter. Sebuah narasi kemudian akan dikarakterisasi oleh enam peran yang disebut Greimas sebagai model aktan (actant) - dimana model aktan ini akan berguna untuk mengarahkan jalannya cerita. Model aktan melibatkan enam buah peran karakter yang masing-masing dihubungkan bukan melalui fungsi, namun melalui relasi yang terjadi antar peran. Eriyanto (2013: 96) menjelaskan keenam peran tersebut beserta fungsinya secara singkat sebagai berikut:

1. Subjek, adalah pelaku utama dalam narasi. Porsi kisahnya paling besar.

2. Objek, adalah tujuan yang ingin dicapai oleh subjek, bisa berupa orang, benda, atau bahkan sebuah kondisi/keadaan.

3. Pengirim, adalah penentu arah kisah. Ia memberikan peraturan dan nilai-nilai dalam sebuah narasi.

4. Penerima, fungsi ini merupakan tujuan dari pengirim dimana segala kisah dari pengirim ditujukan padanya.

5. Pendukung, fungsi utama karakter ini adalah mendukung atau membantu subjek untuk mencapai objek.

6. Penghambat, memiliki fungsi sebaliknya dari pendukung, yakni untuk menghalangi subjek mencapai objeknya.

Greimas melihat adanya keterikatan antara satu karakter dengan karakter lainnya, dimana secara sederhana dibagi menjadi tiga jenis relasi struktural (Eriyanto, 2013: 9697). Pertama, relasi struktural antara subyek versus obyek (sumbu hasrat atau keinginan/ axis of desire). Obyek adalah tujuan yang ingin dicapai oleh subyek, dimana hubungannya adalah hubungan langsung yang dapat diamati secara jelas dalam sebuah teks. Kedua, relasi antara pengirim versus penerima (sumbu pengiriman/ axis of transmission). Disini, pengirim akan memberikan nilai, aturan atau perintah agar obyek bisa tercapai, sementara penerima adalah manfaat setelah obyek berhasil dicapai oleh subyek. Ketiga, relasi struktural antara pendukung versus penghambat (sumbu kekuasaan/ axis of power). Dalam sumbu 
ini, pendukung dikisahkan melakukan sesuatu untuk membantu subyek agar bisa mencapai obyek, dan sebaliknya penghambat melakukan sesuatu untuk mencegah subyek mencapai obyek.

Berdasarkan penjabaran keenam peran dan ketiga sumbu relasi struktural tersebut, maka berikut adalah gambaran model aktan menurut Greimas:

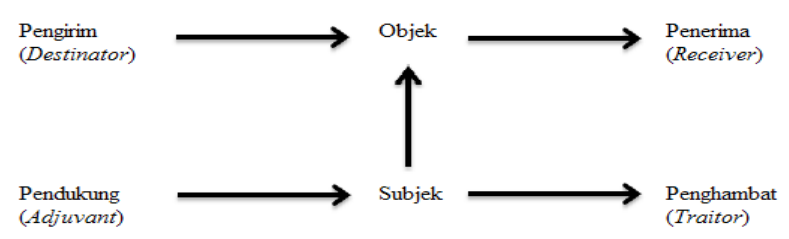

Gambar 2.4.1: Model Aktan (Eriyanto, 2013: 96)

\section{HASIL DAN PEMBAHASAN}

Pada laporan utama Tempo edisi 2-8 Februari 2015 "Peluru-Peluru Pemburu Cicak". Hal menarik yang dilihat pertama adalah terkait profil tokoh yang terlibat dan dinarasikan sebagai karakter yang dominan dalam teks Tempo.

Berikut adalah model aktan yang menggambarkan relasi karakter dalam laporan utama berjudul 'Peluru-Peluru Pemburu KPK' (Tempo edisi 2-8 Februari 2015):

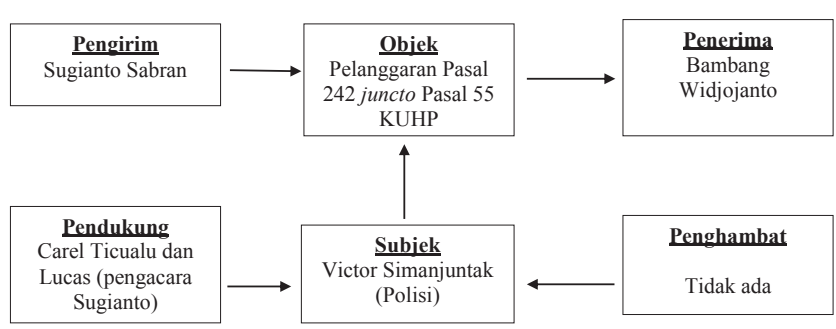

Pada model aktan tersebut diatas, terdapat lima karakter yaitu (1) Sugianto Sabran, (2) Lucas dan (3) Carel Ticualu, (4)Victor Simanjuntak (Polisi), dan (5) Bambang Widjojanto dengan komposisi satu orang dari Pihak POLRI dan tiga orang dari pihak diluar KPK dan POLRI. Namun sebagai sumbu utama pelaporan yaitu Sugianto Sabran, dan Carel Ticualu, Lucas, sedangkan dari pihak KPK ada satu orang, yaitu Lucas dan Carel yang adalah pengacara Bambang sejak pengaduan Bambang ke polisi pada tahun 2010. Pihak yang diwawancarai ada 4 (empat) yaitu Carel, Lucas, Sugianto dan Victor, sedangkan Bambang dan/atau pihak pengacara Bambang tidak menjadi narasumber namun menjadi pihak yang diceritakan.

Bambang Widjojanto adalah Wakil Ketua KPK yang ditangkap pada pagi hari sesaat mengantarkan anaknya ke sekolah. Bambang ditangkap pada 23 Januari 2015 di depan sekolah anaknya. Kisah penangkapan Bambang diliput besar-besaran oleh berbagai media massa pada saat itu. Disebutsebut dalam berbagai media bahwa aksi penangkapan Bambang merupakan aksi balas dendam POLRI setelah penetapan Budi Gunawan sebagai tersangka suap dan gratifikasi yang diumumkan pada 12 Januari 2015. Setelah penetapan Budi Gunawan sebagai tersangka, pencalonannya sebagai kandidat terkuat dan satu-satunya sebagai Kapolri tersendat dan menimbulkan berbagai pro-kontra di masyarakat.

Pembuatan surat tugas untuk pembentukan 'TIM SILUMAN' jelas diakui oleh para pemimpin POLRI dalam hal ini Bareskrim dan para pelaku lapangan penangkapan Bambang Widjojanto. Dalam teras berita disebutkan dengan jelas bahwa Mabes Polri membentuk tim untuk memperkarakan pemimpin KPK.

“... Markas Besar Polri membentuk tim untuk memperkarakan pemimpin KPK. Setelah Bambang Widjojanto ditangkap dan dua wakil ketua dilaporkan ke polisi, Abraham Samad kini dibidik..." (Tempo edisi 2-8 Februari 2015, hal. 28)

Penangkapan Bambang Widjajanto dilakukan secara sistematis, diatur sedemikian rupa dan melibatkan banyak pihak dan lembaga. Diawali dengan laporan Sugianto Sabran yang melaporkan ke polisi bahwa telah terjadisangkaantindakanhukum yang dilakukan oleh Bambang. Laporan yang dilakukan oleh Sugianto Sabran dilakukan dengan sengaja dan dengan pertimbangan 
waktu yang tepat. Meskipun Sugianto Sabran yang melaporkan Bambang Widjojanto ke kepolisian, namun Sugianto tidak sendiri dan bukan inisiatif dari Sugianto.

“...Beberapa jam setelah Komisi Pemberantasan Korupsimengumumkan penetapan tersangka suap kepada Komisaris Jenderal Budi Gunawan, pada 13 Januari 2015, telepon Sugianto terus berdering. Anggota Komisi Hukum Dewan Perwakilan Rakyat 2009-2014 dari PDI Perjuangan yang tinggal di Pangkalan Bun, Kalimantan Tengah, itu dikontak dua pengacara yang dikenalnya sejak lima tahun lalu..." (Tempo edisi 2-8 Februari 2015, hal. 30)

Cuplikan berita diatas, diletakkan oleh Tempo sebagai pembuka dalam artikel laporan utama. Kata kunci dalam cuplikan diatas adalah pada kata "beberapa jam", "terus berdering", dan "dikontak." Kata "beberapa jam" artinya tidak lama atau dalam waktu sesegera mungkin yang berarti nama Sugianto Sabran sudah ada dalam rencana sebelumnya hanya menunggu momen atau waktu yang tepat. Rencana untuk menghubungi Sugianto yang pada tahun 2010 pernah berurusan dengan Bambang dalam sengketa Pemilihan Kepada Daerah (Pilkada) Bupati Kotawaringin Barat. Dalam cuplikan wawancara langsung, Sugianto mengatakan "...saya diminta pak Lucas menggugat lagi karena ini saat yang tepat...” (Tempo edisi 2-8 Februari 2015, hal 30).

Sugianto mengatakan 'saat yang tepat' yang berarti bahwa mantan tim pengacara yaitu Carel Ticualu dan Lucas sudah mempersiapkan jauh-jauh hari saat menggugat lagi dikarenakan bukti yang dimiliki sudah cukup untuk melengkapi alat bukti. Dua hari kemudian setelah Bambang mengumuman Budi Gunawan sebagai tersangka suap dan gratifikasi, Sugianto terbang ke Jakarta pada 15 Januari 2015, dimana pada tanggal 19 Januari mengajukan pengaduan secara resmi bahwa Bambang Widjojanto telah melakukan perbuatan pidana dengan menyuruh saksi memberikan keterangan tak sesuai dengan kenyataan.

Selanjutnya pada babak kedua dari edisi
Tempo 2-8 Februari 2015 ini juga ditemukan tulisan berjudul "Jejaring Pengacara Para Penggugat" yang menyebutkan beberapa tokoh lain yaitu Johan Budi, Badrodin Haiti, Budi Waseso, dan Viktor sebagai Deputi Pencegahan. Sedangkan nama Muhammad Suherman merupakan saksi dalam sidang gugatan Sugianto Sabran tahun 2010. Suherman adalah pelapor yang bersaksi bahwa kubu Sugianto membagi-bagikan amplop uang dan foto-foto pembagian uang itu menggugurkan kemenangan Sugianto.

Tempo menuliskan Johan Budi segera menelepon Badrodin Haiti, pada saat itu Badrodin sedang menggelar rapat dengan penasehat ahli dan perwira utama Mabes Polri, Budi Waseso hadir dalam rapattersebut. Melalui telepon, Badrodin mengatakan tidak mengetahui soal penangkapan Bambang, demikian pula dengan Budi Waseso sebagai Kepala Bareskrim.

Tempo mencatat bahwa Budi Waseso menjelaskan bagaimana proses penyelidikan dan penyidikan di Bareskrim Polri, bahwa surat perintah penangkapan tidak harus ditandatangani oleh Kabareskrim. Hal ini dikarenakan penyidik bersifat independen dan keputusan di lapangan adalah keputusan penyidik. Sementara itu, dalam Peraturan Polori Nomor 14 Tahun 2012 tentang Manajemen Penyidikan Tindak Pidana, tidak diatur secara spesifik mengenai penanggungjawab surat penyidikan dan pembentukan tim penyidikan. Dalam Pasal 33 ayat 3 hanya disebutkan penyidik yang menangkap seorang tersangka wajib dilengkapi surat perintah yang ditandatangani oleh atasan.

Berdasarkan apa yang dijelaskan oleh Budi Waseso ini tampak bahwa Budi Waseso sebagai Kepala Bareskrim tidak selalu mengikuti dan menandatangani surat penyidikan dan penyelidikan. Namun Tempo juga menuliskan bahwa pada pasal 78 , tidak disebutkan secara spesifik siapa yang disebut sebagai atasan penyidik meskipun pada ayat 1 menyebutkan bahwa pejabat terendah sebagai atasan adalah kepala Badan Reserse. Pasal yang membingungkan ini digunakan oleh Budi Waseso untuk menjelaskan 
mengapa Budi Waseso tidak tahu menahu mengenai penangkapan Bambang Widjojanto.

Sedangkan Victor, pemimpin penyidik dalam penangkapan Bambang, menyatakan bahwa Bambang Widjojanto layak untuk ditangkap karena tergolong kasus yang berat. Victor menyatakan bahwa bukti-bukti sudah kuat dan telah memeriksa enam saksi perkara dan tiga saksi ahli. Meskipun tidak dijelaskan dengan persis sebenarnya kapan kesaksian tersebut dibuat mengingat pendeknya jarak antara waktu kunjungan Sugianto Sabran ke Bareskrim dengan waktu penangkapan Bambang. Selain itu, polisi menggunakan dua ahli hukum pidana dan seorang ahli bahasa untuk mengukuhkan kesaksian di hadapan notaris sebagai dokumen untuk menjerat Bambang.

Di bagian terakhir babak kedua ini, Tempo mewawancarai narasumber dari warga pangkalan Benteng, yang menjadi saksi dalam sidang pada tahun 2010. Saksi tersebut adalah Muhammad Suherman, dia menyatakan bahwa Bambang memintanya menyampaikan fakta dan menjaga etika. Suherman juga menyatakan bahwa sebenarnya ada saksi palsu dalam sidang. Suherman dalam Tempo (edisi 2-8 Februari 2015, hal 33) mengatakan "Mereka tak saya kenal, tapi menyatakan telah memberikan keterangan palsu di sidang," ujarnya. "Salah satunya mengaku bernama Kusmiadi."

Kisah dalam babak ketiga ini diawali dengan rentetan kasus yang muncul setelah penangkapan Bambang. Zulkarnaen dan Adnan Pandu Praja dilaporkan menerima suap Rp 5 Milyar dan mobil Toyota Camry ketika menjadi Kepala Kejaksaan Tinggi Jawa Timur tahun 2011. Pengadunya adalah mantan Ketua Dewan Perwakilan rakyat Daerah Jawa Timur, Fathorrasjid. Fathorrasjid dituntut Zulkarnain hingga dihukum enam tahun karena terbukti melakukan korupsi sebesar Rp 8.5 Milyar dalam proyek yang sama dengan tuduhan penyuapan.

Sedangkan Adnan Pandu Parja dilaporkan kuasa pemilik saham PT Daisy Timber di Berau, Kalimantan Timur. Adnan dilaporkan telah mengambil saham perusahaan secara illegal. Victor menyatakan kasus Adnan dan Zulkarnaen agak sulit dicari buktinya. Justru Samad yang buktinya kuat telah membantu seseorang membuat kartu identitas dengan menggunakan kartu keluarganya guna mengurus paspor.

Sebagai penutup, Victor menyatakan bahwa bukti-bukti sudah kuat mengenai pelanggaran hukum oleh ketiga komisioner KPK. Dalam pernyataannya, Viktor secara eksplisit menyatakan

“...dengan begitu, KPK tak lagi punya pemimpin yang akan memutuskan pemeriksaan terhadap Budi Gunawan jika gugatan praperadilan penetapan sebagai tersangka ditolak hakim Pengadilan Jakarta Selatan. "Jika Abraham Samad menjadi tersangka, KPK hancur," ucap Viktor. (Tempo edisi 2-8 Februari 2015, hal 33).

Serangan POLRI kepada KPK ini seakan memberi kesan bahwa POLRI mengahalalkan segala cara demi menyelamatkan Budi Gunawan (sang calon Kapolri) yang tidak jadi dilantik malah menjadi tersangka kasus korupsi (analisis subbab IV.2.1 tentang 'Ada Apa Dengan Budi Gunawan').

Laporan utama Tempo edisi 9-15 Februari 2015 "Dalam Bidikan 'Koalisi Besar' diawali dengan teras berita yang mengungkapkan bahwa Markas Besar Kepolisian sedang mengerahkan para penyidiknya untuk membidik pemimpin KPK sekaligus menghambat pemeriksaan Budi Gunawan, Hendropriyono dan Hasto Kristiyanto.

Berikut adalah model aktan yang pertama tentang skenario pelaporan Abraham Samad:

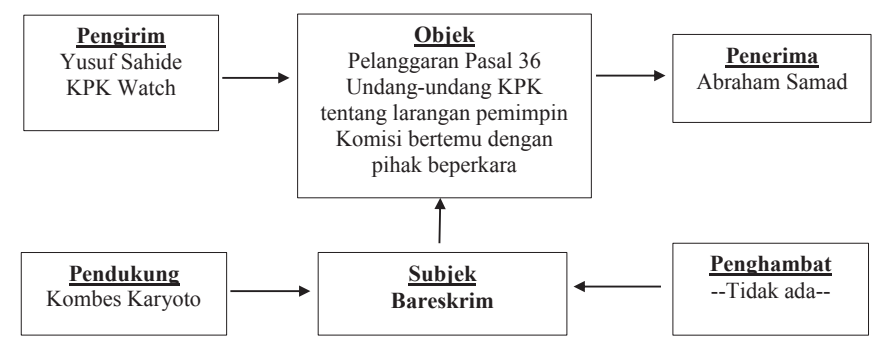

Pada model aktan tersebut diatas, karakter yang terlibat adalah pihak POLRI 
yaitu Bareskrim dan Kombes Karyoto, sedangkan pihak KPK ada nama Abraham Samad, serta tokoh diluar KPK dan POLRI yaitu Yusuf Sahide dari KPK Watch. Laporan Yusuf Sahide ditujukan kepada Bareskrim. Berdasar pada Pasal 36 Undangundang KPK tentang larangan pemimpin Komisi bertemu dengan pihak beperkara, maka Polisi bergerak untuk mengajukan Samad telah telah melakukan pelanggaran terhadap UU tersebut. Yusuf Sahide yang ditulis oleh Tempo dengan label 'mengaku' dari KPK Watch melaporkan Abraham Samad telah melanggar Pasal dalam UU tersebut dikarenakan bertemu dengan Hasto Kristiyanto dari pihak PDIP. Sedangkan tidak ditemukan penghambat dalam model aktan tersebut.

Hal ini sedikit berbeda dengan model aktan kedua yang ditemukan dalam narasi Tempo pada babak pertama ini, dimana Kombes Kartoyo yang semula menjadi pendukung subjek (Bareskrim) untuk mencapai tujuan (objek), kemudian menjadi pengirim pada model aktan kedua dengan objek yang berbeda. Pergeseran relasi karakter dalam sebuah narasi dalam hal ini sangat mungkin terjadi bergantung pada bagaimana alur dan penokohan dalam cerita.

Berikutnya adalah terbitan Tempo edisi 16-22 Februari 2015 dengan judul cover “Teror untuk KPK." Tulisan yang menjadi fokus analisis dalam penelitian ini (babak pertama) adalah artikel utama yaitu "Malam di restoran Cepat Saji.” Pada babak pertama ini dikisahkan bagaimana teror untuk KPK tersebut secara kronologi terjadi, dimana kisah diangkat dari sudut pandang Endang Tarsa (sebagai bagian dari KPK).

Pada babak pertama ini, dikisahkan oleh Tempo bagaimana relasi karakter dengan mengambil setting lokasi di restoran cepat saji Mc Donald's Larangan, Ciledug, Banten. Berikut adalah gambaran relasi karakter 'Malam di Restoran Cepat Saji' dengan model aktan:

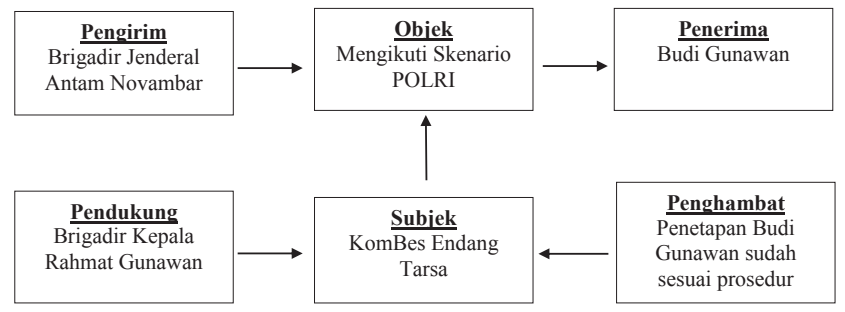

Pada model aktan diatas tampak bagaimana relasi diantara para tokoh dalam babak pertama yang menggambarkan Endang Tarsa sebagai tokoh kunci untuk menggagalkan penetapan Budi Gunawan sebagai tersangka. Posisi Endang Tarsa yang merupakan tokoh kunci yang menyaksikan seluruh proses praperadilan, menunjuk penyidik, dan yang menandatangani surat perintah penyidikan (Tempo edisi 1622 Februari 2015, hal. 6). Artinya Endang mempunyai peran yang strategis dalam kisah penetapan Budi Gunawan.

Dalam artikel disampaikan bahwa Endang tidak serta merta bersedia dengan tawaran Antam dengan dua skenario tersebut. Endang berkali-kali mengucapkan 'terima kasih' atas tawaran Antam. Selain itu Endang menyatakan bahwa penetapan tersangka Budi Gunawan sudah sesuai prosedur Undang-Undang KPK yang mengatur penetapan tersangka yang didasari dua alat bukti dan tak perlu memanggil calon tersangka.Artinya, alat bukti sudah terpenuhi sehingga penetapan Budi Gunawan sebagai tersangka sudah memenuhi ketentuan KPK.

Pertemuan dengan Endang terjadi 2 kali pada hari yang berurutan, pada artikel disebutkan demikian (Tempo edisi 16-22 Februari 2015):

a) Hal. 34, paragraf ke-1: “...Restoran cepat saji Mc Donald's di Larangan, Ciledug, Banten, seperti biasa ramai pada Minggu malam pekan lalu. Satu keluarga merayakan ulang tahun anaknya di ruang khusus yang tersekat dinding kaca. Dalam suasana seperti itulah sejumlah polisi yang kini berbeda institusi bertemu..."

b) Hal. 34, paragraf ke-3: “...itu pertemuan kedua setelah pada Sabtu Malam di tempat yang sama..." 
c) Hal. 36, paragraf ke-3: “...Endang diundang bertemu lagi pada Minggu malam, "saya tidak puas dengan jawaban kang Endang kemarin," kata Agung Setia seperti yang ditirukan seseorang yang mendengar cerita Endang...”

Dari data diatas terungkap bahwa pertemuan di restoran Mc Donald's terjadi dua hari berturut-turut yaitu Sabtu Malam dan Minggu Malam. Pada caption foto Restoran Mc Donald's disebutkan bahwa tanggal pertemuan tersebut adalah 13 Februari 2015, pada hari Jumat. Namun jika merujuk pada hari Sabtu dan Minggu maka pertemuan tersebut terjadi pada $14^{-15}$ Februari 2015.

Berdasarkan data yang dihimpun Tempo berjudul 'Ini Kisah Penyidik KPK Dipaksa Ikut Skenario Perwira Polisi,' (20 Februari 2015) menuliskan bahwa Endang diundang bertemu lagi. Agung mengulangi permintaan agar Endang mengikuti skenario polisi. Sedangkan Antam meminta Endang mundur dari jabatan Direktur Penyidikan KPK dengan surat yang sudah disiapkan.

Pembicaraan mengeras karena Endang bertahan sepertijawaban malam sebelumnya. Ia terus-menerus mengucapkan "terima kasih" atas tawaran yang disampaikan koleganya di Kepolisian itu. Menurut seorang penyidik, Endang juga mengatakan tak ingin mundur dari jabatan itu.

Hasil pertemuan tersebut menunjukkan unsur pemaksaan yang dilakukan Antam Novambar dan Komisaris Besar Agung Setia, terhadap Endang Tarsa agar mengundurkan diri sebagai Direktur Penyidikan Komisi Pemberantasan Korupsi. Alasan lain mengapa Antam dan Agung "ngotot" ingin kembali bertemu Endang? Berdasarkan (Sunudyantoro, 2015, 'Ini Kisah Penyidik KPK Dipaksa Ikut Skenario Perwira Polisi,' http://pemilu.tempo.co/, diakses 27/11/16) pada pertemuan sebelumnya, Endang bersikukuh bahwa penetapan tersangka Budi Gunawan telah dilakukan sesuai dengan prosedur. Ia mengutip Undang-Undang KPK yang mengatur penetapan tersangka didasari dua alat bukti dan tak perlu memanggil calon tersangka lebih dulu.

Selanjutnya di malam kedua, Antam dan Agung nampaknya kembali menemukan jalan buntu, karena Endang tetap bersikukuh tidak ingin mengikuti instruksi keduanya dan juga mengatakan tak ingin mundur dari jabatan itu. Merujuk pada artikel yang dituliskan Sunudyantoro (http://pemilu. tempo.co/, diakses 27/11/16), usai mendengar penjelasan dari Endang, tiba-tiba Antam menjentikkan jari tangannya. Rupanya, ia memberi kode kepada orang-orang yang duduk di teras McDonald's. Enam orang masuk dalam sekejap, termasuk seorang polisi wanita. Mereka diperkenalkan oleh Antam sebagai anggota Brigade Mobil. "Ini anggota saya. Mereka akan menuruti apa pun perintah saya kepada kamu,"ujarnya. Melihat situasi seperti itu, dapat dibayangkan wajah Antam ketika berbicara dengan Endang seperti film-film mafia di layar kaca. Di sisi lain ucapan Antam menunjukkan nada mengancam Endang, dengan kata lain, apabila Endang tidak menuruti perintahnya, maka akan terjadi sesuatu pada dirinya bahkan keluarganya.

Terdapat tiga bagian dalam analisis model aktan. Pertama, relasi struktural antara subjek dan objek, relasi ini disebut juga relasi hasrat atau axis of desire. Pada artikel ini Endang Tarsa digambarkan sebagai seseorang yang harus mengikuti skenario yang dibuat oleh POLRI. Skenario tersebut ada dua yaitu: (1) Endang bersaksi dalam sidang pra-peradilan penetapan Budi Gunawan oleh KPK. Bahwa penetapan Budi Gunawan sebagai tersangka atas desakan Abraham Samad dan wakilnya.

“...Endang diminta menyatakan bahwa
penetapan tersangka calon Kepala Polri
yang telah disetujui Dewan Perwakilan
Rakyat itu dilakukan atas desakan
Ketua KPK Abraham Samad dan
wakilnya, Bambang Widjojanto...”
(Tempo edisi 16-22 Februari 2015, hal
34).

Skenario berikutnya (kedua) adalah Endang mengundurkan diri dari KPK, bahkan surat sudah disiapkan. Dalam artikel disebutkan demikian: 
“... Antam meminta Endang mundur dari jabatan Direktur Penyidikan $K P K$ dengan surat yang sudah disiapkan..." (Tempo edisi 16-22 Februari 2015, hal 36).

Endang Tarsa yang merupakan orang penting dalam penetapan Budi Gunawan sebagai tersangka diposisikan sebagai orang yangsekaligusbisadilobbyuntukkepentingan POLRI. Pada bagian ini, Endang ditampilkan sebagai sosok dengan karakter yang lemah, tidak berintegritas, membutuhkan bantuan, dan tidak komit pada pendirian. Meskipun di bagian awal diceritakan bahwa Endang berkali-kali menolak tawaran Antam dengan dasar bahwa penetapan Budi Gunawan sudah sesuai prosedur KPK. Endang Tarsa sebagai tokoh yang sangat strategis posisinya dalam bagian cerita ini, namun sekaligus sangat lemah dan tampak tidak berintegritas terutama ketika dihadapkan pada sulitnya membuat keputusan ketika kemudian anaknya menjadi taruhannya.

Dalam konteks ini, Endang Tarsa merupakan representasi dari KPK yang berada pada posisi sulit. Disisi lain ia harus bertanggung jawab terhadap pekerjaanya. Endang Tarsa sudah melakukan hal tersebut. Disebutkan dalam artikel pertemuan harus sampai dua kali hingga Endang Tarsa menyerah dengan ajakan POLRI.

Kedua, relasi anatar pengirim (destinator) versus penerima (receiver) atau disebut juga sebagai sumbu pengiriman (axis of transmission). Pada bagian ini pengirim adalah Brigjen Antam Novambar dan penerima adalah Budi Gunawan. Antam Novambar mempunyai relasi yang kuat dengan Budi Gunawan. Disebutkan dalam artikel kalau Antam Novambar merupakan Direktur Reserse Umum Kepolisian Daerah Bali sedangkan saat itu Budi Gunawan sebagai Kapolda Bali. Dalam artikel hanya disebut sebagai kepalanya (kepala Antam Novambar). Relasi antara Antam Novambar tersurat sekaligus tersirat dalam bagian terakhir dalam babak pertama tulisan Tempo edisi 16-22 Februari 2015, hal. 36.

"Antam menyalami dan memeluk Endang. Direktur Reserse Umum
Kepolisian daerah Bali ketika Budi Gunawan jadi kepalanya itu menghubungi seseorang melaluitelepon yang ia panggil "Jenderal." Ia melapor telah berhasil menjalankan misi.

Antam Novambar digambarkan sebagai bawahan yang patuh pada atasannya. Sistem senioritas dan garis komando pada kepolisian menjadikan Antam akan selalu patuh pada posisi diatasnya. Maka ketika Antam melaporkan kepada seseorang yang dia panggil 'jenderal' sangat wajar. Dikarenakan posisi Jenderal lebih tinggi dibandingkan Brigadir Jenderal. Apalagi dalam teks disebutkan bahwa Antam Novambar adalah 'bawahan' Budi Gunawan ketika di Polda Bali. Tersirat dan tersurat bahwa Jenderal Budi Gunawan adalah atasan Antam Novambar dalam tulisan babak pertama Tempo tersebut.

Kredibilitas KPK dipertanyakan begitupun kredibilitas POLRI sebagai lembaga penegak hukum, ketika KPK mengusik lembaga tertinggi di Indonesia yang menangani kasus kriminal. Narasumber dari babak pertama adalah Choirul Anwar, Manajer McD pada hari itu. Choirul mengkonfirmasi bahwa terjadi pertemuan KPK dan POLRI, meski Choirul tidak tahu apayang dibicarakan oleh kedua belah pihak. Narasumber berikutnya adalah 'seseorang' yang dikatakan dalam teks mendengar kisah pertemuan tersebut dari cerita Endang. Narasumber berikutnya adalah Frederich Gunadi, pengacara Budi Gunawan. Nara sumber dari pelaku secara langsung belum muncul pada babak pertama ini.

Kedua narasumber yaitu 'seseorang' dan Frederich Gunadi mewakili dari kedua belah pihak. Secara meyakinkan kedua belah pihak berusaha untuk mengkonfirmasi kejadian yang berlangsung. Prinsip cover both side berusaha diupayakan Tempo yang mengedapankan keberimbangan sudut pandang melalui orang kedua, bukan pelaku utama dari peristiwa. Namun keberimbangan sumber belum tampak kuat, hal ini dikarenakan naskah cerita semua berasal dari sudut pandang 'seseorang' yang berada di pihak Endang Tarsa. Sedangkan 
manajer McD hanya untuk konfirmasi terjadi pertemuan. Kemudian, dari pihak Antam Novambar memberikan 'konfirmasi' dari kisah pertemuan Endang-Antam, namun tidak langsung berkaitan dengan peristiwa, hanya memberikan konteks bahwa Endang akan menjadi saksi yang mengejutkan dalam sidang pra peradilan penetapan Budi Gunawan sebagai tersangka oleh Komisi Pemberantasan Korupsi.

Pada babak kedua dalam laporan utama Tempo edisi 16-22 Februari 2015, merupakan kisah lanjutan setelah pertemuan di McDonald (babak pertama). Pada bagian ini dilakukan konfirmasi ke banyak pihak mengenai peristiwa tersebut. Babak kedua ini merupakan bridgeatau jembatan untuk menuju kepada akhir dari solusi kisah pertemuan Antam Novambar dan Endang Tarsa. Beberapa tokoh diminta keterangan oleh Tempo berkaitan dengan peristiwa di Mc Donald's Larangan, Ciledug, Banten.

Beberapa profil karakter dan tokoh yang terlibat adalah Antam Novambar, Endang Tarsa, Nur Cholis (Komisioner Komisi Nasional Hak Asasi Manusia). Nur Cholis diminta hadir untuk mendengarkan kisah Endang Tarsa. Lalu ada Frederich Yunadi, Pengacara Budi Gunawan, Agung Setia dan Bambang Widjojanto (pihak KPK yang mendapat laporan dari Endang Tarsa).

Babak kedua ini dimulai dengan pernyataan Antam akan dugaan intimidasi yang dilakukan kepada Endang Tarsa (penyidik KPK). Berikut ini isi pernyataan para narasumber:

a) Hal. 37, paragraf ke-1: “...tak ada terror-teror. Kamimalah bersalaman bahkan berpelukan..."

b) Hal. 37, paragraf ke-2: “...saya bantu dengan meloloskan anaknya, ujarnya. "Bayangkan, itu semua penghargaan buat Endang dan anaknya."

c) Hal. 37, paragraf ke-11: “...saya katakan kepada mereka, kamu kawal ya. Jangan sampai lepas, jangan sampai diambil orang. Karena dia mau bersaksi untuk kita," ujarnya.
Kutipan langsung tersebut dikatakan oleh Antam. Antam menyangkal telah melakukan intimidasi, bahwa anggota Brigadir Mobil yang ia bawa justru disiapkan untuk mengawal Endang bukan untuk intimidasi. Antam justru melihat hal tersebut sebagai bentuk penghargaan kepada Endang dan anaknya. Apalagi menurut Antam, anaknya Endang tak lulus tes kesehatan sebagai salah satu syarat kenaikan tingkat. Antam konsisten bahwa apa yang dilakukan kepada Endang Tarsa bukan merupakan intimidasi. Antam bahkan memposisikan dirinya sebagai penolong terhadap kesulitan yang dialami anak Endang Tarsa. Melalui kehadiran anggota Brimob, pelukan, dan jaminan lulus bagi anak Endang, hal ini menjadi bukti bahwa tidak ada intimidasi, menurut Antam. Namun ketiga pernyataan Endang tersebut dinegasikan oleh Antam sendiri melalui telepon pada Endang Tarsa yang oleh Endang telepon dari Antam dipengeras suara dan didengarkan oleh pimpinan KPK, kesaksian Endang direkam dan dikomentasikannya.

Berikut ini ucapan Antam yang dikutip oleh Tempo: "Kasihan orang Sumedang ini. Sebentar lagi matahari akan gelap, bulan akan gelap" (hal. 37 paragraf ke-9). Pada bagian berikutnya, Tempo melakukan konfirmasi kepada Endang Tarsa. Berikut ucapan Endang Tarsa: “..Anda tahu jalan ceritanya tak begitu," katanya kepada Muhammad Rizki dari Tempo (hal. 37 paragraf ke-3).

Endang menolak untuk memberikan konfirmasi. Dia menjawab dengan singkat kepada wartawan Tempo bahwa kisahnya diputar balikkan. Dari apa yang dikatan oleh Endang Tarsa, menyatakan bahwa seolah wartawan Tempo telah mendapatkan cerita pertemuan tersebut secara lebih lengkap. Statemen Endang Tarsa hanya menguatkan, apa yang sudah ditemukan oleh Tempo di lapangan.

Sementara Agung Setia menolak untuk berkomentar (hal. 37 paragraf ke-4), sebaliknya dia meminta Tempo untuk langsung konfirmasi pada Endang. Agung Setia adalah Kepala Subdirektorat Pencucian uang Badan Reserse Kriminal 
Markas Besar Kepolisian Negara Republik Indonesia. Agung Setia bersama dengan Antam menemui Endang untuk melakukan negosiasi berkaitan penetapan Budi Gunawan sebagai tersangka. Berikut ini yang dikatakan oleh Agung Setia: “...coba tanya yang bersangkutan saja," ujarnya pada Singgih Soares dari Tempo (hal. 37 paragraf ke-4).

Disisi lain, Bambang Widjojanto yang mendapatkan laporan dari Endang Tarsa pada keesokan harinya, menyatakan bahwa: "...kami harus bergerak cepat untuk mengidentifikasi penerornya," kata Bambang (hal. 37 paragraf ke-6). Yang dimaksud dengan bergerak cepat adalah, Bambang membentuk 4 (empat ) tim, satu tim bergerak ke Mc Donald's sedangkan (tim, peneliti) lainnya bergerak ke rumah Endang Tarsa untuk menjemput anak dan istrinya lalu membawanya ke tempat yang aman.

Salah satu pengacara Budi Gunawan yakni Frederich Yunadi mengatakan bahwa ia tidak tahu mengapa dan sudah lupa pada akarnya (hal. 37 paragraf ke-10). Apa yang disampaikan oleh Yunadi tersebut mengingatkan kepada publik bahwa Endang Tarsa adalah bagian dari POLRI yang ditugaskan sebagai penyidik di KPK. Sebagai bagian dari POLRI, maka apa yang dikatakan Yunadi itu merupakan sebuah pernyataan tidak langsung bahwa seharusnya Endang Tarsa mengikuti apa perintah pemimpinnya di POLRI. Apalagi POLRI mengenal garis komando yang kuat, dimana yang disebut sebagai 'akar' adalah POLRI sebagai rumah induk dari Endang Tarsa.

Sebagai penutup di babak kedua ini, Tempo mengambil pernyataan Antam Novambar mengenai ketidakhadiran Endang Tarsa dalam sidang gelar perkara. Antam menyatakan bahwa: “...Dia bertahan di KPK karena anaknya dijanjikan akan dimasukkan kesana," ujarnya (hal. 37 paragraf ke12). Pernyataan Antam Novambar ini menghadirkan anak dari Endang Tarsa yang seolah-olah menjadi penentu setiap keputusan Endang Tarsa. Jika di babak pertama dikatakan bahwa Endang Tarsa bersedia mengikuti permintaan Antam
Novambar dikarenakan anak Endang Tarsa, Brigadir Kepala Rahmat Gunawan saat ini bekerja di Kepolisian Daerah Metro Jaya.

Sebagai penutup dari edisi 16-22 Februari 2015 ini, babak ketiga menyebut beberapa nama sebagai penentu keputusan atau juga orang paling berpengaruh untuk dapat menyelesaikan kasus yang disebutkan dalam bagian babak pertama. Adapun karakter yang terlibat adalah Joko Widodo (Presiden RI), Jenderal Endriartono Sutarto (Mantan Panglima TNI, saat itu salah satu Tim Konsultasi KPK-POLRI), Jenderal Badrodin Haiti (Wakil Kepala Polri - saat itu), dan Bambang Widjojanto (Wakil Pimpinan KPK). Pada bagian ini, Tempo melakukan konfirmasi kepada pihak-pihak yang dinilai mempunyai kedudukan untuk mengambil keputusan yang signifikan terhadap kasus ini. Maka tokoh yang diwawancarai adalah Presiden RI, dimana KPK bertanggung jawab langsung, Wakapolri saat itu, dan mantan Panglima TNI sebagai Tim Konsultasi KPKPOLRI.

Pada babak ketiga ini, para pucuk pimpinan negeri ini angkat bicara soal dugaan intimidasi yang dilakukan oleh pihak POLRI. Sekaligus konfirmasi dari para pucuk pimpinan POLRI sendiri. Meskipun menggunakan kutipan tidak langsung, dan sangat mungkin sumber beritanya dari empat pimpinan KPK yang bertemu dengan Presiden Jokowi, namun apa yang ditulis oleh Tempo menegaskan bahwa Presiden sudah mengetahui tentang kasus ini dan segera kasus diusut. Berikut kutipan tidak langsung pernyataan Presiden RI: Presiden menyatakan terror harus dihentikan. Ia meminta polisi menangkap pelakunya (hal. 37 paragraf ke-13).

Menanggapi perintah Pesiden tersebut, maka Badrodin Haiti menyatakan bahwa:

“...menurut Badrodin, Budi Waseso membenarkan kabar bahwa Antam Novambar diberitugas mendatangai Endang Karena mendengar ia hendak mengundurkan diri dari KPK. "Selain tim inti dari reserse, ada tim pendukung yang direkrut dari luar Bareskrim,"katanya..." (Tempo edisi 16- 
22 Februari 2015, hal. 37).

Bagi POLRI, perintah Presiden itu dilaksanakandengancaramemintakonfimasi kepada Budi Waseso mengenai apa yang sedang terjadi dan mengkonfirmasi siapakah Endang dan kepentingan Endang dalam kisruh KPK dan POLRI. Badrodin Haiti, berdasarkan konfimrasi dari Budi Waseso, menyatakan bahwa pertemuan di Mc Donald tersebut adalah pertemuan biasa. Sementara itu, Badrodin Haiti meminta Endang untuk melaporkan teror yang menimpanya.

Senada dengan Budi Waseso yang dinyatakan pada Endang, Antam mengatakan bahwa pertemuan tersebut dikarenakan Antam dan Endnag berasal dari kampung yang sama. Apa yang disampaikan oleh Antam seolah-olah pertemuan tersebut merupakan pertemuan reunian atau keguyuban biasa dikarenakan mereka berdua berasal dari kampung yang sama. Selain sekampung, Antam mengatakan bahwa ia mendekati Endang dikarenakan sesama perwira di Mabes Polri. Apa yang dilakukan oleh Antam mengingatkan kepada Endang dan juga kepada publik bahwa sejatinya KPK dan POLRI adalah sesaudara kandung namun berbeda tugas dan kewajiban.

\section{"Sebagai insan Polri, saya merasa perlu mengajak dia memberikan kesaksian sebenarnya. Dia lupa, dia bisa bekerja di KPK Karena dia Polisi," kata Antam (Tempo edisi 16-22 Februari 2015, hal. 38).}

Artikel ini ditutup dengan pelaporan kasus intimidasi terhadap anggota penyidik KPK kepada Komisi Nasional Hak Asasi Manusia.Selainintimidasimelaluipertemuan di McDonald, Endang Tarsa juga melaporkan bahwa dia diikuti orang tidak dikenal dan memaksa melihat isi telepon. Laporan tersebut melengkapi bahwa intimidasi yang dilakukan kepada anggota penyidik KPK adalah sangat serius. Keluarga Endang Tarsa kini tinggal di rumah perlindungan Komisi Pemberantasan Korupsi.

Berdasarkan model aktan yang dilakukan pada relasi antar karakter dan bagaimana karakter ditampilkan dalam kisah pada laporan utama Tempo dari tiga edisi (2-8 Februari, 9-15 Februari, dan 16-22 Februari 2016). Ketiga edisi Tempo membahas mengenai lumpuhnya KPK yang secara sengaja dirancang secara sistematis dan terencana. Ketiga artikel yaitu PeluruPeluru Pembunuh Cicak, Dalam Bidikan Koalisi Besar, dan Malam di Restoran Cepat Saji menampilkan karakter KPK dan POLRI sebagai pemburu dan buruan. Cicak dan buaya digambarkan bukan sebagai saudara sekandung namun sebagai pemangsa dan mangsanya. Menggunakan metafora cicak dan buaya jilid dua, KPK dan POLRI tampil seperti lawan dalam laga namun dengan kekuatan yang berbeda dan tak berimbang.

Pada artikel "Malam di Restoran Cepat Saji" para penyidik KPK yang berasal dari POLRI merupakan senjata yang digunakan Bareskrim (sebagai bagian dari POLRI) untuk melemahkan KPK dari dalam internal KPK sendiri. Hal ini ditunjukkan dengan terseretnya Endang Tarsa dalam konflik KPK dan POLRI. Menggunakan skenario yang mengintimidasi keluarga, Endang Tarsa dihadapkan pada profesionalisme dan juga melindungi keluarga. Dari kisah Endang Tarsa yang mewakili KPK didapatkan kesimpulan bahwa usaha melemahkan KPK melalui intimidasi dan pemaksaan kepada penyidik yang merupakan bagian dari Polri.

Pola kedua yang digunakan adalah dengan menggunakan pasal-pasal untuk menjerat pimpinan KPK. Pada artikel "Dalam Bidikan Koalisi Besar" dijelaskan bahwa delik pasal aduan tersebut dilaporkan oleh masyarakat yang bukan bagian dari KPK dan POLRI dimana aduan tersebut diajukan kepada Bareskrim berdasarkan laporan masyarakat yang sebenarnya dipertanyakan. Tempo beberapa kali dalam tulisannya menyebutkan bahwa seolah-olah dibuat dengan mendadak dan penuh pemaksaan serta dicari-cari, maka usaha untuk memperkarakan para pimpinan ditempuh melalui perangkat hukum.

Pola ketiga adalah intimidasi terhadap kinerja KPK. Hal ini berkaitan dengan kasus yang sedang ditangani oleh KPK. Penarikan berkas yang sedang diusut oleh KPK dimana 
berkas yang diminta oleh Bareskrim adalah kasus yang berkaitan dengan PDIP. Selain itu muncul nama-nama tokoh dari PDIP dan orang dekat Megawati. Hal ini menjadi simpul yang kuat untuk mengindikasikan bahwa Konflik KPK-POLRI ini sebenarnya adalah bagian kecil dari konflik yang lebih besar yang melibatkan partai besar di Indonesia, yaitu PDIP. Hal ini tergambarkan dalam artikel "Dalam Bidikan Koalisi Besar."

\section{SIMPULAN}

Narasi pemberitaan tentang KPK dan POLRI dalam Majalah Tempo sebagai produk teks berita memiliki karakter yang sangat mirip dengan kisah-kisah bercerita lainnya (karya fiksi/ dongeng/ film, dll.) Narasi sendiri seringkali disebut sebagai representasi dari sebuah peristiwa atau rangkaian kejadian-kejadian yang dikisahkan kembali. Kesimpulan dari penelitian ini adalah KPK dinarasikan sebagai pihak yang lemah, penuh dengan masalah, dan melanggar etika sehingga harus ditangani dan diselesaikan oleh Bareskrim Polri. Dalam ketiga kisah ini, POLRI yang diwakili Bareskrim dinarasikan sebagai lembaga yang mengayomi dan melakukan penertiban terhadap pelanggaran Undang-Undang. KPK kemudian direpresentasikan sebagai pihak yang salah karena melanggar aturan, sedangkan POLRI adalah pihak yang benar karena menegakkan aturan. Melumpuhkan KPK dengan cara yang sistematis merupakan langkah benar, tepat, dan sesuai prosedur yang dilakukan oleh POLRI sebagai lembaga penegak hukum.

Kelemahan dalam penelitian narasi masalah sumber referensi. Hal ini disebabkan analisa dalam narasi tidak bisa keluar dari teks yang ada. Interteks hanya digunakan sebagai analisa konteks dari teks. Oleh karena itu perlu dilakukan penelitian lanjutan mengenai model model narasi pada bentuk teks lainnya yang berbeda dalam penelitian ini. Penelitian ini menggunakan teks yang merupakan bentuk pelaporan jurnalistik investigasi. Maka kesulitan intertekstualitas dalam penelitian ini adalah menjadi problem utama dalam analisa.

\section{ACKNOWLEDGEMENT}

Penelitian ini merupakan Penelitian Dosen Pemula yang didanani oleh Direktorat Riset dan Pengabdian Masyarakat Direktorat Jenderal Penguatan Riset Dan Pengembangan, Kementerian Riset, Teknologi dan Pendidikan Tinggi, sesuai dengan Surat Perjanjian Penugasan Pelaksanaan Program Penelitian Nomor: 003/SP2H/P/K7/KM/2016 tanggal 25 April 2016 


\section{REFERENSI}

Eriyanto. (2013). Analisis Naratif: Dasardasar dan Penerapannya dalam Analisis Teks Berita Media. Jakarta: Kencana.

Birowo, M. Antonius (Editor). (2004). Metode Penelitian Komunikasi. Yogyakarta: Gitanyali.

Elliot, Jane. (2005). Using Narrative in Social Research. London UK.

Eriyanto. (2013). Analisis Naratif (Dasardasar Penerapannya Dalam Analisis Teks Berita). Jakarta: Kencana Prenada.

Harsono, Andreas. (2010). Agama Saya Adalah Jurnalisme. Yogyakarta: Penerbit Kanisius.

Santana, Septiawan. (2004). Jurnalisme Investigasi. Jakarta: Yayasan Obor Indonesia.

\section{Jurnal:}

Hardy, Melissa. Bryman, Alan. (2004). Handbook of Data Analysis: The Uses of Narrative in Social Science Research. SAGE Research Methods Online.

Majalah Tempo Edisi 2-8 Februari 2015

Majalah Tempo Edisi 9-15 Februari 2015

Majalah Tempo Edisi 16-22 Februari 2015

Forum diskusi KPK Polri http://forum.detik. com/kpk-watch-t889191.html, diakses 27/11/16).

Zainal Arifin Mochtar, Pengajar Ilmu Hukum, Ketua PUKAT FH UGM (dalam http:// pukatkorupsi.ugm.ac.id/? $\mathrm{p}=3882$, diakses 27/11/16) Tentang UU KPK

Muhtarom, 2015 berjudul 'Ini Bunyi Perpu Pengangkatan Plt Pemimpin KPK https://m.tempo.co 